Article

REHMAN, A. ${ }^{1}$

QAMAR, R. ${ }^{*}$

FAROOQ, M. ${ }^{1}$

QAMAR, J. ${ }^{1}$

HASSAN, F. ${ }^{1}$

\section{Competitive AbIlity OF SANTA-MARIA (Parthenium hysterophorus L.) WITH SPRING MAIZE}

\author{
Capacidade Competitiva de Losna-Branca (Parthenium hysterophorus L.) \\ com Milho de Primavera
}

\begin{abstract}
In recent decades, allelopathy has gained considerable attention in sustainable agricultural systems. In the current situation, an attempt has been made to investigate the optimal competition period for weed control in maize. Experiments were designed in randomized complete block design and Parthenium hysterophorus was naturally infested in experimental plots during the spring season 2014 to determine the critical competition period for weed control in maize. The relations between grain yield and different competition durations were determined via regression analyses. The experiment comprised seven treatments viz, control treatment, competition for $30,45,60,75,90$ and 105 days after emergence. The results suggested that a weedfree period (control treatment) of maize was enough to provide acceptable grain yield. Whole season different competition periods and weed-free plots were included in the experiment for yield comparison. The highest grain yield was obtained from plot kept weed-free (control treatment). The results clearly indicated that P. hysterophorus was competitively more aggressive and its control in maize crop provide maximum grain yield.
\end{abstract}

Keywords: competition, weeds, yields.

RESUMO - Nas últimas décadas, a alelopatia adquiriu atenção considerável em sistemas agrícolas sustentáveis. Na situação atual, foi feita uma tentativa para investigar o periodo de competição ideal para o controle de ervas daninhas no milho. Os experimentos foram planejados em blocos inteiramente casualizados e a Parthenium hysterophorus foi infestada naturalmente em parcelas experimentais durante a temporada de primavera de 2014, para determinar o periodo crítico de competição para o controle de ervas daninhas no milho. As relações entre o rendimento de grãos e a duração da competição foram determinadas através de análises de regressão. $O$ experimento compreendeu sete tratamentos, ou seja, controle, competição por 30, 45, 60, 75, 90 e 105 dias após emergência. Os resultados sugerem que um periodo sem ervas daninhas (controle) de milho foi suficiente para proporcionar um rendimento de grãos aceitável. Periodos de competição diferentes durante a temporada completa e as parcelas sem ervas daninhas foram incluidas no experimento para comparação de rendimento. $O$ maior rendimento de grãos foi obtido a partir da parcela mantida sem ervas daninhas (controle). Os resultados do estudo indicaram claramente que P. hysterophorus foi competitivamente mais agressiva, e que o controle deve ser realizado na cultura do milho para providenciar o rendimento máximo de grãos.

Palavras-chave: competição, plantas daninhas, rendimentos.

1 University College of Agriculture, University of Sargodha, Pakistan. 


\section{INTRODUCTION}

In Pakistan, maize (Zea mays L.) is the leading cereal crop after wheat (Triticum aestivum L.) and rice (Oryza sativa L.), having an area of about 1.130 million hectares with a total annual production of 4.69 MT (Pakistan, 2014-2015). In the world, United States, China, and Brazil are the main producers of maize, producing approximately 563 of the 717 million metric tons/year. Maize share in human nutrition is about $72 \%$ starch, $10 \%$ protein, $4 \%$ fat and an energy density of $365 \mathrm{kcal} / 100 \mathrm{~g}$ (Ranum et al., 2014). Although maize is one of the premier crops consumed by almost $50 \%$ of the inhabitants, it is also very sensitive to weed competition at early growth stages (Kumar and Sundari, 2002; Singh et al., 2005). Weed infestation and competition can result in considerable yield losses, from 35 to $83 \%$, as it has been reported (Usman et al., 2001). Parthenium strong competitive and allopathic behavior can decrease up to $90 \%$ the yield of crops in the herbaceous component of natural plant communities (Mahadevappa, 1997). Significant production can be achieved through an effective weed management strategy, which is developed by understanding thoroughly the ecological relations in weed-maize competition.

Parthenium hysterophorus is an increasing concern among the world farming community, due to its ecological, economic and social effect (Luken and Thieret, 1997). Moreover, it is declared as a high invasive and notorious weed among about 73 different types of new plants that have invaded the country (Qureshi et al., 2014). P. hysterophorus ranked at the top among the world's ten notorious weed floras (Callaway and Ridenour, 2004) and has entered nearly 30 countries, where it has caused economic harm to agro-ecosystems (Shabbir and Bajwa, 2007; Nigatu et al., 2010).

Parthenium has the characteristics of competition ability and allelopathic interference, which drastically delays the growth of different monocot and dicot plants (Marwat et al., 2008; Kaur et al., 2014). The known allelopathic effect on crops may be constructive and unconstructive for maize production systems. Allelo-chemicals are recommended to control weeds in order to avoid the use of costly and pollutant artificial herbicides (Kruse, 2000; Belz, 2007). Herbicide has no dominated effect for the control of $P$. hysterophorus, which is the basic invasion in crop ecosystems in Pakistan and other countries (Khan et al., 2013). Maize production losses due to presence of this weed have not yet been determined. However, it is necessary to investigate the duration of this weed's competition in maize, without exceeding the economic threshold level (Martin et al., 2001). It is necessary to find out the critical weed-crop competition duration, which may seriously reduce crop production, and fields should be kept weed-free during this period to avoid the harmful effects caused by weeds.

Considering the importance of maize and weeds, it is necessary to study the aspects of weed science that aimed at maintaining the profitability of farming operations and alertness of the farmers about the harmful effects of $P$. hysterophorus. Such studies will help scientists and farmers in decision-making processes about weed management. This study was thus designed to determine the response of maize and $P$. hysterophorus to various periods of days after emergence, with the purpose to figure out yield losses due to Parthenium hysterophorus in maize and to find out competition indices and threshold levels in maize.

\section{MATERIAL AND METHODS}

\section{Site and study}

This study was conducted on loam soil to investigate the competitive ability of Parthenium hysterophorus on maize under agro-ecological conditions, in Sargodha, in the Agronomic Research area, University College of Agriculture, University of Sargodha during the spring season 2014. This research area is located at $32.08^{\circ} \mathrm{N}$ and $72.67^{\circ} \mathrm{E}$ and the General Elevation of land from sea level is $193 \mathrm{~m}$.

The climate of the region is subtropical semi-arid, with an annual average rainfall of $400 \pm 5 \mathrm{~mm}$, and more than $70 \%$ of the rainfall occurs during June-September (Agro-Metrological Lab, University of Sargodha). The mean monthly minimum temperature is $10^{\circ} \mathrm{C}$ in January, and the maximum temperature is $40^{\circ} \mathrm{C}$ in July. The soil belongs to the Hafizabad series (finesilty, mixed, hyperthermic typic calciargids) and the soil texture is loam and heavy loam. (Khan, 
1986). Selected chemical and physical characteristics of soil were studied before sowing: pH $7.8 \pm 0.1$, electrical conductivity $2.18 \pm 0.3 \mathrm{dS} \mathrm{m}^{-1}$, soil organic matter content $0.70 \%$, total $\mathrm{N} 0.05 \%$, available phosphorus $60 \mathrm{mg} \mathrm{kg}^{-1}$ and exchangeable potassium $80 \mathrm{mg} \mathrm{kg}$. The experimental design was a randomized complete block one, having three replications with a net plot size of $5 \mathrm{~m} \times 3 \mathrm{~m}\left(15 \mathrm{~m}^{2}\right)$ and with each plot consisting of four rows. Maize hybrids (Hi-corn 11) were sown on March $15^{\text {th }}, 2014$ on the ridges using a seed rate of $25 \mathrm{~kg}^{-1}$ haintaining a rowto-row distance of $75 \mathrm{~cm}$, while plant-to-plant distance was kept at $25 \mathrm{~cm}$. The experiment consisted of seven treatments in which the co-existing period of maize and $P$. hysterophorus was varied, viz. Control treatment, and Competition for 30 45, 60, 75, 90 and 105 days after emergence. Fertilizer at the rate 120: 80: 60 NPK kg ha ${ }^{-1}$ was used. All the phosphorus and potash along with half nitrogen were applied at sowing, while the rest of nitrogen was top dressed during the $2^{\text {nd }}$ irrigation. Six irrigations were applied throughout crop duration. The crop was harvested on July $10^{\text {th }}, 2014$ when crop was fully mature. All the other weeds were removed manually, except for Parthenium, in order to maintain the prescribed competition period. Weed removal from plots was carried out at different competition periods. Full-season different competition periods and weed-free plots were included in the experiment for yield comparison. All the cultural operations were kept normal and uniform. The evaluated variables were: number of plants $\mathrm{m}^{2}$, plant height $(\mathrm{cm})$, stem diameter $(\mathrm{cm})$, number of cobs $\left(\mathrm{m}^{-2}\right), 1000$ grain weight $(\mathrm{g})$ and grain and biological yield $\left(\mathrm{t} \mathrm{ha}^{-1}\right)$. Data were analyzed statistically using SAS (SAS, 2008), while a regression analysis to find out the linear competitive response of maize with $P$. hysterophorus was performed by using Microsoft Excel 2007.

\section{RESULTS AND DISCUSSION}

\section{Parthenium hysterophorus effect on number of maize plants $\left(\mathbf{m}^{-2}\right)$}

The regression analysis (Table 1 ) on the number of plants $\mathrm{m}^{-2}$ showed that $P$. hysterophorus reduced $(\mathrm{P} \leq 0.05)$ the number of plants with an increase in competition duration (Figure 1). A significant increase in the number of maize plants $\left(13.43 \mathrm{~m}^{-2}\right)$ was recorded in the control treatment, while the number of plants was minimum $\left(8.10 \mathrm{~m}^{-2}\right)$ at $105 \mathrm{DAE}$ of competition with $P$. hysterophorus. The vigorous growth of $P$. hysterophorus affected maize growth significantly. Results supported what was found by Coleman and Gill (2003), who reported that yield losses increased with the increase in competition duration, which is associated with a lower number of plants.

\section{Parthenium hysterophorus effects on plant height (cm) of maize}

Figure 2 shows the regression response of $P$. hysterophorus with maize that is acknowledged in Table 1 . The regression analysis describes a decrease $(\mathrm{P} \leq 0.05)$ in plant height with an increase in competition duration. A higher plant height $(228.10 \mathrm{~cm})$ was recorded in the control plot, while a lower $(176.33 \mathrm{~cm})$ plant height occurred at $105 \mathrm{DAE}$ of competition with $P$. hysterophorus. It might be due to a lower availability of nutrients, which are necessary for proper plant growth. This finding is in conflict with results by Alford et al., (2004) who reported that plant height was not affected by weed infestation.

Table 1 - Regression analysis of various studied maize parameters

\begin{tabular}{|c|c|c|c|c|}
\hline Parameter & A & B & $\mathrm{R}^{2}$ & Probability \\
\hline Number of plants $\mathrm{m}^{-2}$ & $14.1352 \pm 0.7296$ & $-0.0419 \pm 0.0109$ & 0.7472 & 0.0120 \\
\hline Plant height $(\mathrm{cm})$ & $234.5112 \pm 6.5181$ & $-0.4161 \pm 0.0975$ & 0.7846 & 0.0079 \\
\hline Stem diameter $(\mathrm{cm})$ & $2.0066 \pm 0.0738$ & $-0.0041 \pm 0.0011$ & 0.7349 & 0.0136 \\
\hline Number of cobs $\left(\mathrm{m}^{-2}\right)$ & $18.8307 \pm 0.9636$ & $-0.0809 \pm 0.0144$ & 0.8630 & 0.0025 \\
\hline 1000-grain weight $(\mathrm{g})$ & $301.7809 \pm 3.9330$ & $-0.3167 \pm 0.0588$ & 0.8528 & 0.0029 \\
\hline Grain yield (ton $\mathrm{ha}^{-1}$ ) & $12.4033 \pm 0.5790$ & $-0.0572 \pm 0.0087$ & 0.8970 & 0.0012 \\
\hline Biological yield (ton ha $^{-1}$ ) & $23.7994 \pm 0.8630$ & $-0.0855 \pm 0.0129$ & 0.8978 & 0.0012 \\
\hline
\end{tabular}




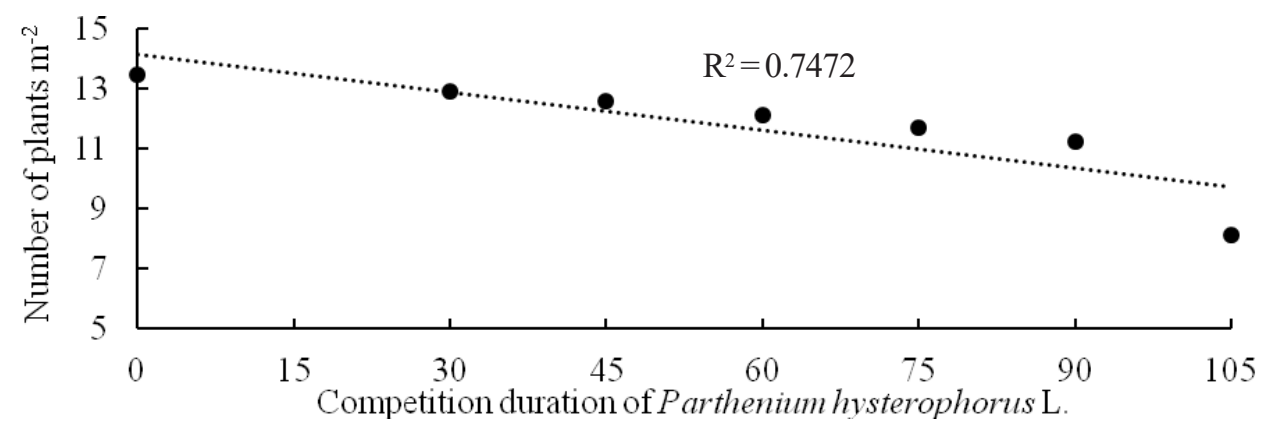

Figure 1 - Number of maize plants $\mathrm{m}^{-2}$ as influenced by various competition duration (days) of Parthenium hysterophorus.

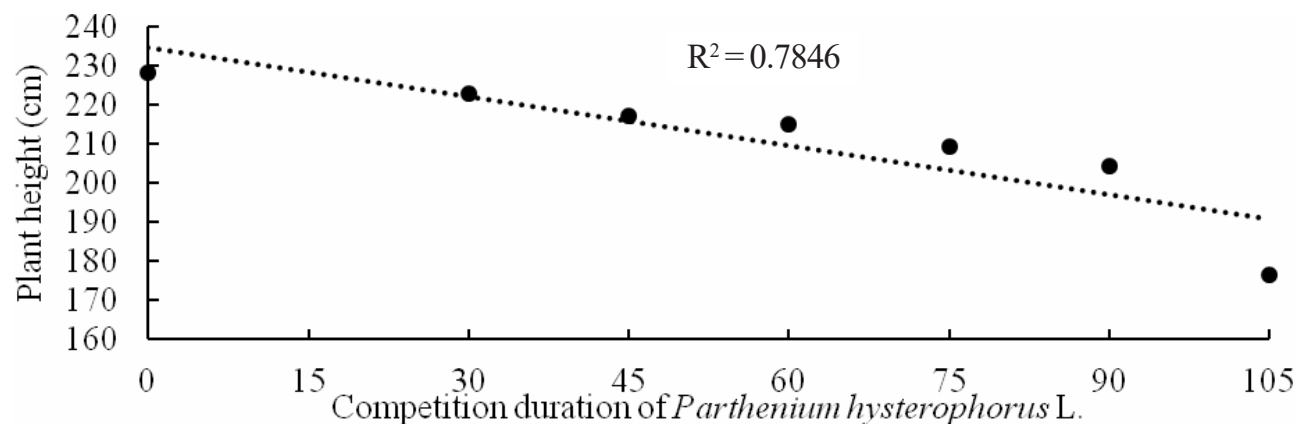

Figure 2 - Maize plant height (cm) as influenced by various competition duration (days) of Parthenium hysterophorus.

\section{Parthenium hysterophorus effects on stem diameter $(\mathrm{cm})$ of maize}

The regression analysis (Table 1) shows a significant effect of $P$. hysterophorus on the maize stem diameter. Highly significant $(\mathrm{P} \leq 0.05)$ differences were observed among various treatments for maize stem diameter. Figure 3 describes a linear decreasing trend with an increase in competition duration with $P$. hysterophorus The thickest $(1.96 \mathrm{~cm})$ and the thinnest $(1.41 \mathrm{~cm})$ stems were obtained in the control treatment and at 105 DAE, respectively. This gradual decrease in the stem diameter might be due to the increase in competition with P. hysterophorus for nutrients, water, light, etc. These findings supported the results by Al-Shebani, (2006) who reported that weeds compete with crop for resources.

\section{Parthenium hysterophorus effects on number of maize cobs $\left(\mathrm{m}^{-2}\right)$}

Competition duration of $P$. hysterophorus had significant $(\mathrm{P} \leq 0.05)$ effect on number of maize cobs (Table 1). The decreasing trend in number of cobs was linear with an increase in competition duration with $P$. hysterophorus (Figure 4). Maximum number of cobs $\left(17.68 \mathrm{~m}^{-2}\right)$ were recorded in control treatment while minimum number of cobs $\left(8.24 \mathrm{~m}^{-2}\right)$ at $105 \mathrm{DAE}$ competition with $P$. hysterophorus where the crop competed for nutrients and other resources. Our results supports the finding of Anafjeh and Chaab, (2012) who also found lower number of cobs with increased weed competition.

\section{Parthenium hysterophorus effects on 1000 grain weight $(\mathrm{g})$ of maize}

Regression analysis of the data depicts that competition duration had significant $(\mathrm{P} \leq 0.05)$ effect on the 1000 grain weight of maize (Table 1). Significant decrease in 1000 grain weight was found with increased competition duration with P. hysterophorus (Figure 5). The highest $(296.31 \mathrm{~g})$ and the lowest $(262.23 \mathrm{~g}) 1000$ grain weight was noted in control and $105 \mathrm{DAE}$ competition with $P$. hysterophorus This decreasing trend might be due to competitive effect for 


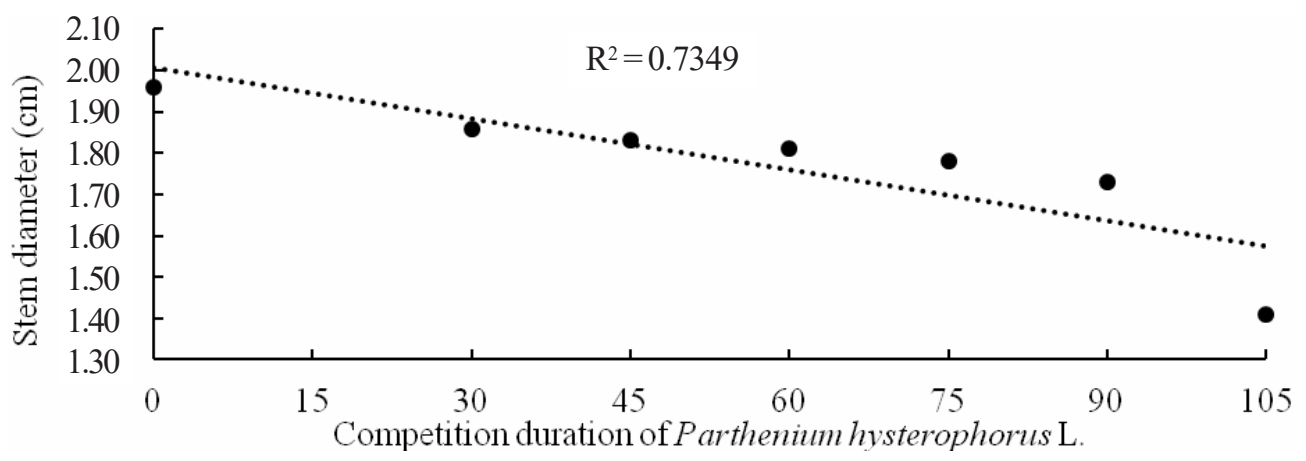

Figure 3 - Stem diameter $(\mathrm{cm})$ of maize as influenced by various competition duration (days) of Parthenium hysterophorus.

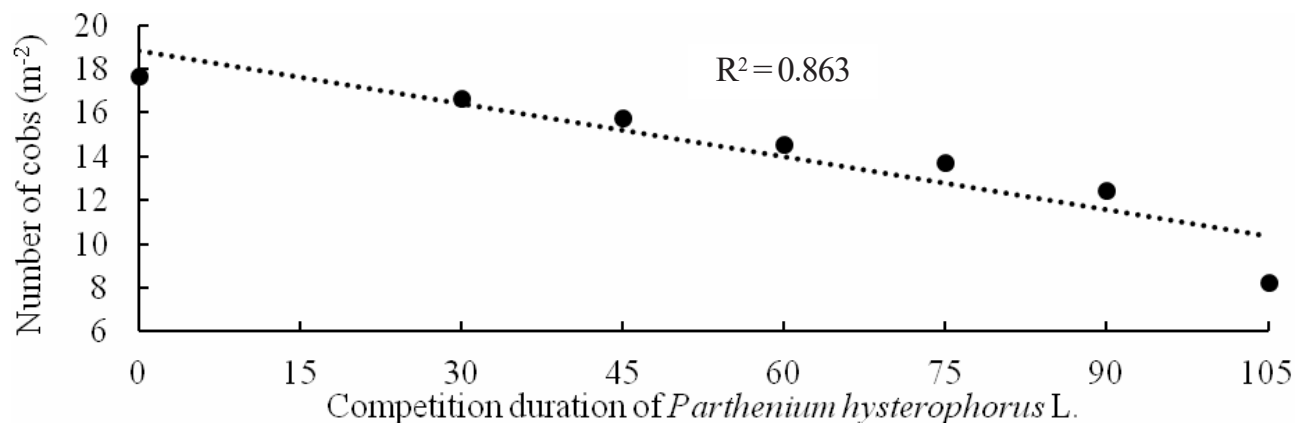

Figure 4 - Number of maize cobs $\left(\mathrm{m}^{-2}\right)$ as influenced by various competition (days) duration of Parthenium hysterophorus.

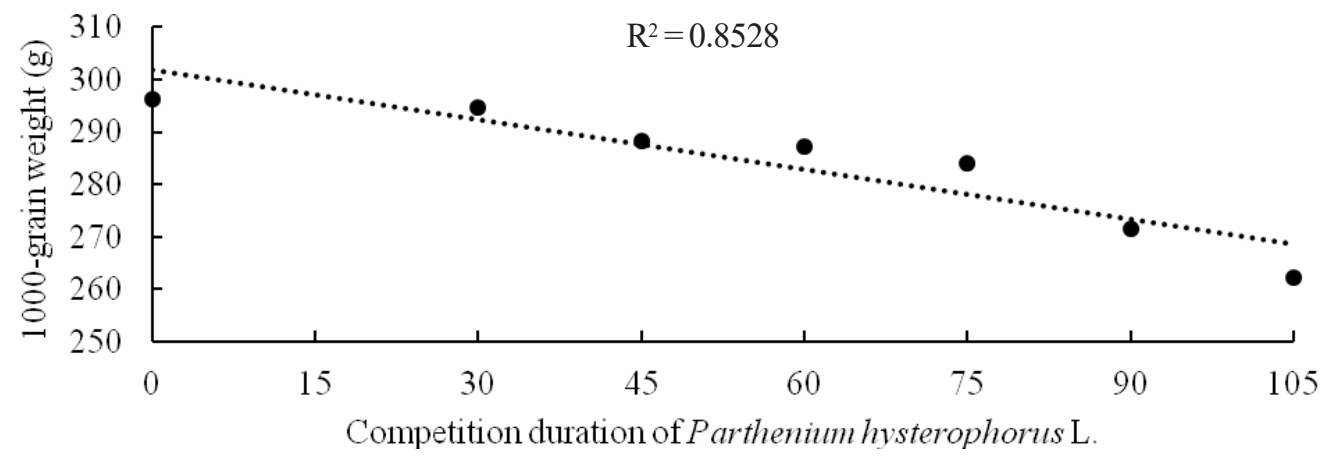

Figure 5 - 1000-grain weight (g) of maize as influenced by various competition duration (days) of Parthenium hysterophorus.

nutrients, water, light between crop plants and weeds. Our study strengthens the results of Khan et al. (2007) who found similar competitive effect on 1000 grain weight in with various competition with weeds.

\section{Parthenium hysterophorus effects on grain yield (ton ha ${ }^{-1}$ ) of maize}

Grain yield was significantly $(\mathrm{P} \leq 0.05)$ affected by different competition duration (Figure 6). The highest (11.65 ton ha $\mathrm{h}^{-1}$ ) and the lowest (5.68 ton ha $\mathrm{ha}^{-1}$ ) grain yield were obtained in control and $105 \mathrm{DAE}$. The reduction in maize yield due to increase in the competition between maize and $P$. hysterophorus was considerably higher; this might be due to its competitive effect that deprived maize of the resources for normal growth. In a competition studies, Khan et al. (2013) reported that weed infestation for longer periods caused failure of maize crop with negligible grain yield. 


\section{Parthenium hysterophorus effects on biological yield (ton ha-1) of maize}

The perusal of the regression analysis (Table 1) indicates that the biological yield of maize was decreased by the increase in the competition duration of $P$. hysterophorus (Figure 7). The biological yield was reduced $(\mathrm{P} \leq 0.05)$ by the competition with $P$. hysterophorus. The highest (22.69 ton ha $\mathrm{h}^{-1}$ ) biological yield was recorded in the control treatment, while the lowest one (13.25 ton ha-1) was at 105 DAE. This research supported the results of Armin et al. (2007), who reported that increases in weed competition periods create dwindling effects on biological yield. They reported that increases in crop-weeds co-existence resulted in a lower biological yield. The minimum biological yield was due to Parthenium competition with maize throughout the crop period (Sajid et al., 2012). Results from this research provide guidelines to maize growers for making decisions about $P$. hysterophorus management based on its competitive effect on maize crops. P. hysterophorus at its later stages offered greater competition to crops. However, results from this study concluded that maize growers should control $P$. hysterophorus within 30 days after emergence, in order to avoid significant grain yield losses.

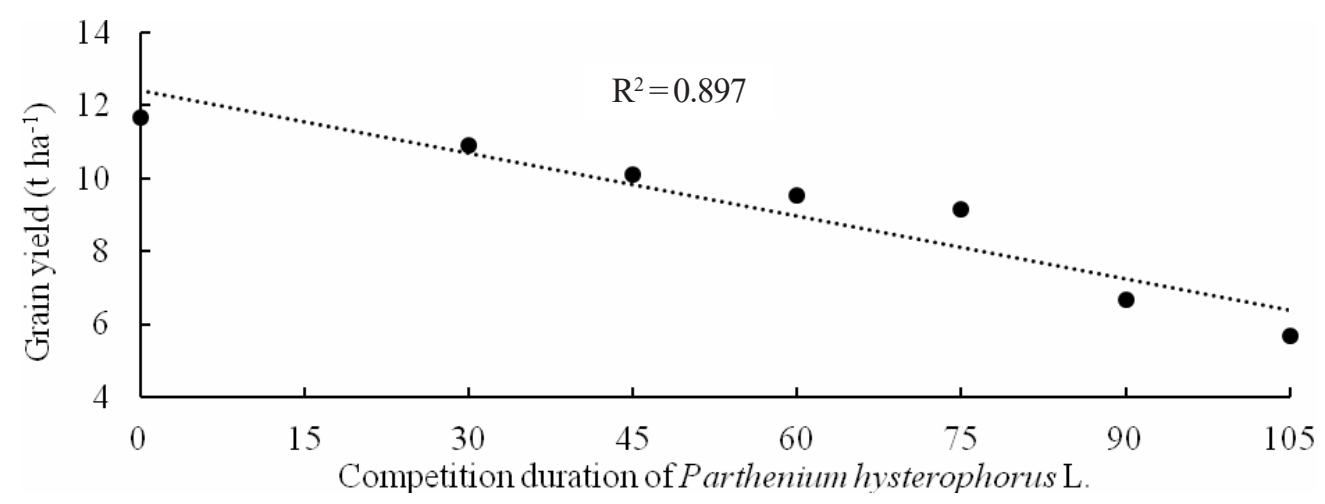

Figure 6 - Maize grain yield (ton ha ${ }^{-1}$ ) as influenced by various competition duration (days) of Parthenium hysterophorus.

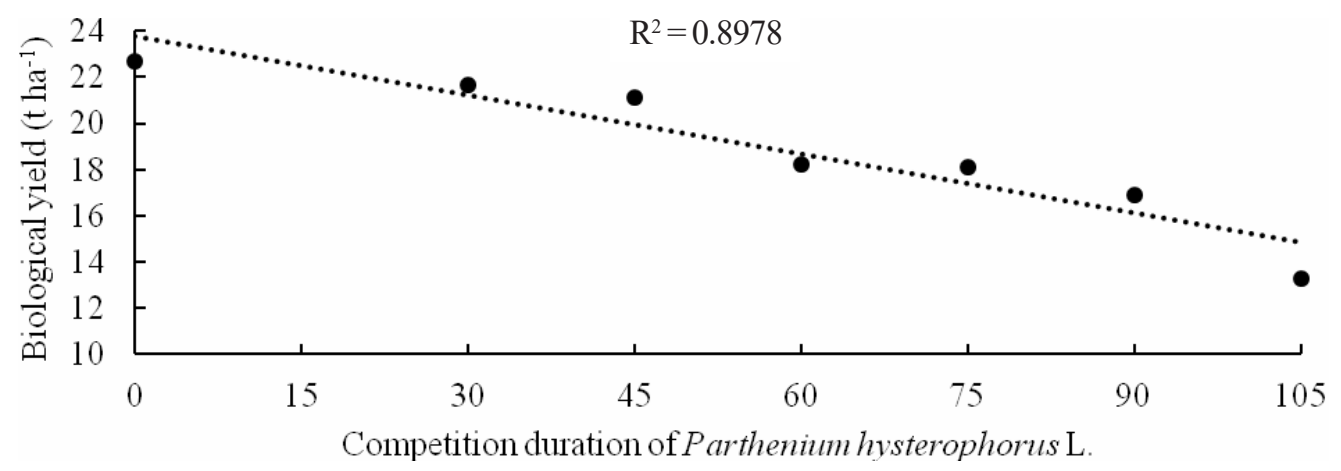

Figure 7 - Maize biological yield (ton ha-1) as influenced by various competition duration (days) of Parthenium hysterophorus.

\section{REFERENCES}

Alford C.M. et al. Using row spacing to increase crop competition with weeds. In: Proceedings of the $4^{\text {th }}$ International Crop Science Congress. Brisbane: 2004.

Al-Shebani Y.A.A. Response of maize to poultry manure in combination with urea fertilization under three hill distances. Ann Agric Sci. 2006;44:15-25.

Anafjeh Z., Chaab A. The effect of various plant densities on competitiveness of corn with natural population of weeds. Int $\mathbf{J}$ Agron Plant Prod. 2012;3:207-12. 
Armin M. et al. Using plant density to increase competition ability in more and less competitive wheat cultivars with Wild oat. Asian J Plant Sci. 2007;6:599-604.

Belz R.G. Allelopathy in crop/weed interactions and update. Pest Manag Sci. 2007;63:308-26.

Callaway R.A., Ridenour W.M. Novel weapons: invasive success and the evolution of increased competitive ability. Front Ecol Environ. 2004;2:436-43.

Coleman R., Gill G. Trends in yielding ability and weed competitiveness of Australian wheat cultivars. In: Proceedings of the 11th Australian Agronomy Conference [cd rom]. Victoria: 2003. Available on: http://www.regional.org.au/au/asa

Kaur M. et al. Effects and management of Parthenium hysterophorus: a weed of global signiûcance. Int Schol Res Not. $2014: 1-12$.

Khan G.S. Need for International Crosschecking and Correlation in Soil Analysis for International Classification Systems. In: Proceedings of the 12th International Forum on Soil Taxonomy and Agro-Technology Transfer: Soil Survey of Pakistan. Lahore: Director General, Soil Survey of Pakistan, 1986. v.2. p.276-93.

Khan I.A. et al. Effect of wild oats (A. fatua) densities and proportions on yield and yield components of wheat. J Agric Biol Sci. 2007;2:26-31

Khan M.A. et al. Differential response of Zea mays L. in relation to weed control and different macronutrient combinations. Sains Malaysiana. 2013;42:1405-11.

Kruse M. Ecological effects of allelopathic plants. A review, Department of Terrestrial Ecology. Silkeborg: 2000.

Kumar S.M.S., Sundari A. Studies on the effect of major nutrients and crop-weed competition period in maize. Indian J Weed Sci. 2002;34:309-10.

Luken J.O., Thieret J.W. Assessment and management of plant invasions. New York: Springer-Verlag, 1997. 324p. (Environmental Management Series).

Mahadevappa M. Ecology, distribution, menace and management of parthenium. In: Mahadevappa M., Patil V.C., editors. Proceedings of the $1^{\text {st }}$ International Conference on Parthenium Management. Dahrwad, India: University of Agricultural, Sciences, 1997. p.1-12.

Martin S.G. et al. Critical period of weed control in spring canola. Weed Sci. 2001;49:326-33.

Marwat K.B. et al. Parthenium hysterophorus L. a potential source of bio herbicide. Pak J Bot. 2008;40:1933-42.

Nigatu L. et al. Impact of Parthenium hysterophorus on grazing land communities in North-Eastern Ethiopia. Weed Biol Manag. 2010;10:143-52.

Pakistan. Ministry of Finance. Economic Survey of Pakistan. 2014-15. 22p.

Qureshi H. et al. Invasive ûora of Pakistan: a critical analysis. Int J Biosci. 2014;4:407-24.

Ranum P. et al. Global maize production, utilization, and consumption. Ann NewYork Acad Sci. 2014;1312:105-12

Sajid H. et al. Determining critical weed competition period in maize (Zea mays L.) sown under different tillage insentities. Pak J Weed Sci Res. 2012;18:474-661.

SAS Institute. SAS online doc 9.13. Cary: 2008.

Shabbir A., Bajwa R. Parthenium invasion in Pakistan a threat still unrecognized. Pak J Bot. 2007:39:2519-26.

Singh H.P. et al. Phytotoxic effects of Parthenium hysterophorus residues on three Brassica species. Weed Biol Manag. 2005;5:105-9.

Usman A. et al. Effect of weed interference and nitrogen on yields of a maize/rice intercrop. Int J Pest Manag. 2001;47:241-6. 